ROCZNIKI HUMANISTYCZNE

Tom LXVIII, zeszyt $3-2020$

DOI: http://dx.doi.org/10.18290/rh20683-8

\title{
ZAGADNIENIE PERIODYZACJI LITERATURY ŁACIŃSKIEJ DOBY REPUBLIKI RZYMSKIEJ
}

\section{WPROWADZENIE}

Literaturoznawcy polscy (podobnie jak zagraniczni) stosują tradycyjny podział literatury rzymskiej na 4 podstawowe okresy literackie ${ }^{1}$ :

1. Okres archaiczny (240-81 r. przed Chr.);

2. Okres cyceroński (81-43 r. przed Chr.);

3. Okres augustowski (43 r. przed Chr. -14 r. po Chr.);

4. Okres cesarstwa (14 r. po Chr. - V wiek po Chr.) $)^{2}$.

Prof. dr hab. KRZYSZTOF TOMASZ WiTCZAK - profesor zwyczajny Zakładu Latynistyki i Językoznawstwa przy Katedrze Filologii Klasycznej Uniwersytetu Łódzkiego; adres do korespondencji: Zakład Latynistyki i Językoznawstwa, Wydział Filologiczny Uniwersytetu Łódzkiego, ul. Pomorska 171/173, 90-236 Łódź; e-mail: krzysztof.witczak@uni.lodz.pl; ORCID: 0000-0001-8895-974X.

${ }^{1}$ Nazwy okresów literackich przywołuję za powszechnie znanym opracowaniem literatury rzymskiej, złożonym z pięciu następujących tomów: (1) Ludwika Rychlewska, Maria Cytowska i Hanna Szelest, Literatura rzymska. Okres archaiczny (Warszawa: Państwowe Wydawnictwo Naukowe, 1996); (2) Kazimierz Kumaniecki, Literatura rzymska. Okres cyceroński (Warszawa: Państwowe Wydawnictwo Naukowe, 1977); (3) Maria Cytowska i Hanna Szelest, Literatura rzymska. Okres augustowski (Warszawa: Państwowe Wydawnictwo Naukowe, 1990); (4) Maria Cytowska i Hanna Szelest, Literatura rzymska. Okres cesarstwa (Warszawa: Państwowe Wydawnictwo Naukowe, 1992); (5) Maria Cytowska i Hanna Szelest, Literatura rzymska. Okres cesarstwa: autorzy chrześcijańscy (Warszawa: Państwowe Wydawnictwo Naukowe, 1994).

2 Pomijam w tym miejscu kwestię literatury chrześcijańskiej, która przez filologów klasycznych dawnego pokolenia zaliczana była do patrologii i zdecydowanie oddzielana od literatury pogańskiej starożytnego Rzymu. Tak czynił m.in. Kazimierz MoRAwsKi, Historia literatury rzymskiej, t. I-VII (Kraków: Akademia Umiejętności, 1909-1921); IDEM, Zarys literatury rzymskiej (Kraków: Polska Akademia Umiejętności, 1922). Także we współczesnych opracowaniach literatura chrześcijańska doby antycznej (zarówno grecka, jak i rzymska) jest zwykle traktowana osobno, choć jest częścią złożonego procesu przenikania się zjawisk literackich późnego antyku. Por. choćby pozycję (5) w przypisie 1. 
Nieco odmienny podział spotykamy $\mathrm{w}$ innym podręczniku literatury rzymskiej3.

Ostatnio prof. Stanisław Stabryła zaproponował zmodyfikowany podział dziejów literatury rzymskiej:

1. Okres rozkwitu republiki ( 240 - ok. 130 r. przed Chr.);

2. Okres zmierzchu republiki (ok. 130-30 r. przed Chr.);

3. Okres augustowski ( 30 r. przed Chr. -14 r. po Chr.);

4. Okres cesarski (14 r. po Chr. $-\mathrm{V}$ wiek po Chr. $)^{5}$.

Mógłby ktoś powiedzieć, że periodyzacja literatury rzymskiej w ujęciu prof. S. Stabryły w niewielkim stopniu odbiega od tradycyjnego podziału. Mamy bowiem wyróżnione 4 kolejne okresy literackie, które mają częściowo innowacyjne, częściowo tradycyjne nazwy oraz nieco zmodyfikowane ramy chronologiczne (w przypadku trzech okresów literackich). Długość trwania poszczególnych okresów literackich w ujęciu tradycyjnym i „innowacyjnym" (proponowanym w monografii Stabryły) różni się jednak dość znacząco, co łatwo można zademonstrować w postaci tabelarycznej.

\footnotetext{
${ }^{3}$ Maria Cytowska i Hanna Szelest, Historia literatury starożytnej, red. Mieczysław Mejor (Warszawa: Wydawnictwo Naukowe PWN, 2006), s. 7. Tu mamy nieco odmienny podział na 5 okresów: 1. Okres archaiczny ( 240 - ok. 90 r. przed Chr.); 2. Okres cyceroński (ok. 90 - ok. 40 r. przed Chr.); 3. Okres augustowski (ok. 40 r. przed Chr. -14 r. po Chr.); 4. Okres cesarstwa (I-III wiek po Chr.); 5. Okres późnego cesarstwa (284-476 r. po Chr.). Niniejsza publikacja jest nieco rozszerzoną i uzupełnioną przez redaktora M. Mejora wersją podręcznika tych samych autorek wydanego 25 lat wcześniej: EADEM, Literatura grecka i rzymska $w$ zarysie (Warszawa: Państwowe Wydawnictwo Naukowe, 1981 (wyd. 2 - 1983, wyd. 3 - 1985)). Publikacja wydana w 2006 r. reprezentuje zatem wcześniejszy, później zmodyfikowany podział literatury rzymskiej na okresy literackie.

${ }^{4}$ Stanisław STABRYŁA, Zarys kultury Grecji i Rzymu (Warszawa: Oficyna Wydawnicza Aspra -JR, Bellona, 2016²), 202-212. Ten sam autor zaproponował wcześniej podobny podział w podręczniku literatury antycznej, zob. Stanisław STABRYŁA, Historia literatury starożytnej Grecji i Rzymu (Wrocław-Warszawa-Kraków: Zakład Narodowy im. Ossolińskich, 2002), 265-483. Należy jednak podkreślić, że periodyzacja literatury rzymskiej została poprzednio powiązana przez autora nie tyle z okresami literackimi, ile raczej z sześcioma epokami historycznymi: 1. epoka archaiczna (od powstania Rzymu do zakończenia I wojny punickiej w 241 r. przed Chr.); 2. epoka rozkwitu republiki (od zakończenia I wojny punickiej do wystąpienia Tyberiusza Grakcha w $133 \mathrm{r}$. przed Chr.); 3. epoka zmierzchu republiki (od 133 r. do bitwy pod Akcjum w 31 r. przed Chr.); 4. epoka augustowska (od bitwy pod Akcjum do śmierci Augusta w 14 r. po Chr.); 5. epoka cesarstwa (14-476 r. po Chr.); 6. epoka państw germańskich na obszarze cesarstwa zachodniorzymskiego, na którą (zdaniem prof. Stabryły) przypada „schyłek literatury rzymskiej” (V-VII wiek po Chr.).

${ }^{5}$ Brak dokładnej granicy finalnej okresu cesarstwa nie jest zaskakujący. W istocie rzeczy, autor stara się zasygnalizować, że wyróżniony okres literacki bynajmniej nie zakończył się wraz $\mathrm{z}$ upadkiem Cesarstwa Zachodniorzymskiego w 476 r. po Chr.
} 


\begin{tabular}{|l|l|l|l|l|}
\hline Chronologia & $\begin{array}{l}\text { Okres 1 } \\
\text { [archaiczny] }\end{array}$ & $\begin{array}{l}\text { Okres 2 } \\
\text { [cyceroński] }\end{array}$ & $\begin{array}{l}\text { Okres 3 } \\
\text { augustowski }\end{array}$ & $\begin{array}{l}\text { Okres 4 } \\
\text { Cesarstwa }\end{array}$ \\
\hline $\begin{array}{l}\text { Długość okresu literackie- } \\
\text { go w ujęciu tradycyjnym }\end{array}$ & około 160 lat & około 38 lat & około 57 lat & około 500 lat \\
\hline $\begin{array}{l}\text { Długość okresu literackie- } \\
\text { go wg prof. S. Stabryły }\end{array}$ & około 110 lat & około 100 lat & około 44 lat & około 500 lat \\
\hline Różnica & -50 lat & +62 lata & -13 lat & bez zmian \\
\hline Różnica (w \%) & $31,25 \%$ & $62 \%$ & $22,81 \%$ & $0 \%$ \\
\hline
\end{tabular}

Tab. 1: Cztery okresy dziejów literatury rzymskiej w ujęciu tradycyjnym i prof. S. Stabryły Źródło: opracowanie własne

Zaproponowany przez prof. Stabryłę podział dziejów literatury rzymskiej wydaje się bezpośrednio nawiązywać do zastosowanego przezeń podziału dziejów Rzymu na 6 kolejnych epok historycznych: A. epoka królewska (753-509 r. przed Chr.); B. epoka wczesnej republiki (509-264 r. przed Chr.); C. epoka rozkwitu republiki rzymskiej (264-133 r. przed Chr.); D. epoka zmierzchu republiki rzymskiej (133-31 r. przed Chr.); E. epoka augustowska (31 r. przed Chr. - 14 r. po Chr.); F. epoka cesarstwa (14-476 r. po Chr.) ${ }^{6}$. W dwóch pierwszych epokach historycznych rodziła się dopiero tradycja piśmiennicza $w$ języku łacińskim, a rzymska literatura piękna pojawiła się w kolejnej (trzeciej) epoce historycznej. Ogólnie jednak (przynajmniej w ujęciu Stabryły) historyczne epoki dziejów Rzymu pokrywają się z okresami rozwojowymi literatury rzymskiej ${ }^{7}$.

Ustabilizowana (czyli dotychczas ogólnie przyjmowana) periodyzacja literatury rzymskiej wymaga, jak sądzę, ponownej weryfikacji zarówno z punktu widzenia definicji okresu literackiego, jak i chronologizacji dziejów języka łacińskiego. Rozwój bowiem każdego języka ściśle łączy się zarówno z dokonaniami literackimi, jak i z dziejami państwowości rzymskiej.

\footnotetext{
${ }^{6}$ STABRYŁA, Zarys kultury, 129-146. Należy zastrzec, że zbliżony (ale nie identyczny) podział dziejów Rzymu na epoki historyczne zastosował ten sam autor w monografii wydanej w 2002 r., por. STABRYŁA, Historia literatury (zob. wyżej, przypis 2).

${ }^{7}$ Badacze zajmujący się periodyzacją dziejów literatury rzymskiej zazwyczaj podkreślają ,a close connection of the division of literary history into periods to the formation of ancient historical epochs", zob. Hubert CANCIK, Helmuth SCHNEIDER, red., Brill's Encyclopaedia of the Ancient World New Pauly, vol. VII (Leiden Boston: Brill, 2005), 703, s.v. Literature. Division into periods.
} 


\section{FAZY ROZWOJOWE JĘZYKA ŁACIŃSKIEGO}

Periodyzacja literatury rzymskiej wiąże się nie tylko z postępem cywilizacyjnym starożytnego Rzymu, ale przede wszystkim z rozwojem języka łacińskiego, który na przestrzeni kilku stuleci znacząco zmienił się równocześnie $\mathrm{w}$ warstwie fonologii, morfologii, składni i słownictwa ${ }^{8}$. Twórcy literatury łacińskiej dysponowali zatem w poszczególnych wiekach nieco innym modelem języka, a także odmiennym zestawem dostępnych gatunków literackich i środków artystycznych.

Językoznawcy wyróżniają 6 zasadniczych faz rozwojowych języka łacińskiego 9 :

1. Łacina wczesnoarchaiczna obejmującą fazę przedliteracką (VII wiek przed Chr. -241 r. przed Chr.);

2. Łacina archaiczna (240-81 r. przed Chr.);

3. Łacina klasyczna (tzw. złota łacina) ( 80 r. przed Chr. - 14 r. po Chr.);

4. Srebrna łacina (14-117 r. po Chr.);

5. Łacina archaizująca (117-180 r. po Chr.);

6. Łacina późna (180 r. po Chr. - VII wiek po Chr.)

Jeżeli porównamy tradycyjny podział na okresy literackie $z$ fazami rozwojowymi języka łacińskiego, to łatwo zauważymy, że niektóre granice wydzielane przez literaturoznawców (między innymi przez M. Brożka, L. Rychlewską, S. Stabryłę) oraz lingwistów-latynistów pokrywają się, inne zaś nie. Dwie wyraźnie opozycyjne względem siebie epoki literackie (cycerońska i augustowska) współtworzą z lingwistycznego punktu widzenia najbardziej reprezentatywny etap rozwoju języka łacińskiego, znany pod nazwą klasycznej albo „złotej” łaciny ${ }^{10}$. Z kolei w jednolitym jakoby okresie literackim doby cesarstwa język łaciński doznaje tak znaczących przemian, że lingwiści bez żadnego problemu wyróżniają 3 dość łatwo uchwytne fazy rozwojowe języka łacińskiego. Na bazie tych dwóch przykładów można by sądzić, że periodyzacja dziejów literatury rzymskiej w niewielkim tylko stopniu wiąże się

\footnotetext{
${ }^{8}$ Te zagadnienia w kolejnych rozdziałach przedstawia szerzej Jan SAFAREwICZ, Zarys historii języka łacińskiego (Wrocław: Zakład Narodowy im. Ossolińskich, Wydawnictwo PAN, 1986).

${ }^{9}$ Gerhard MeISER, Historische Laut- und Formenlehre der lateinischen Sprache (Darmstadt: Wissenschaftliche Buchgesellschaft, 2006²), 2.

${ }^{10}$ Należy jednak zauważyć, że literaturoznawcy niemieccy wydzielają niekiedy „das goldene Zeitalter der römischer Literatur” (złoty okres literatury rzymskiej), przypadający na lata $83 \mathrm{r}$. przed Chr. - 17 r. po Chr., czyli na okres cyceroński i augustowski („Ciceronisches und augusteisches Zeitalter”), zob. Wilhelm Sigmund TeUfFEL, Geschichte der römischen Literatur, neu bearbeitet von Wilhelm Kroll und Franz Skutsch, B. I: Die Literatur der Republik (Leipzig-Berlin: B.G. Teubner, $\left.1916^{6}\right)$, s. IX, 311.
} 
z periodyzacją dziejów języka łacińskiego. Ale czy ten pogląd można uznać za słuszny? Chyba nie całkiem.

\section{POJĘCIE OKRESU LITERACKIEGO}

Okres literacki stanowi pewną fazę procesu historycznoliterackiego, określoną ramami chronologicznymi i charakteryzującą się swoistym układem zjawisk literackich, które w sposób bezsporny odróżniają ją od innych faz ewolucyjnych ${ }^{11}$. Każdy okres literacki charakteryzuje się nie tylko jednością programową i spójnością dążeń w obrębie dominującego prądu, ale też wyraźnym podobieństwem wytworów literackich w ujęciu tematycznym, strukturalnym lub stylistycznym.

Zarówno w okresie cycerońskim, jak i augustowskim możemy mówić o dominujących zjawiskach i prądach literackich, a także o wyraźnie już zarysowanych grupach poetyckich o sprecyzowanych poglądach i jednoznacznej tradycji literackiej, np. o grupie neoteryckiej w okresie cycerońskim; względnie o trzech rywalizujących kołach literackich w okresie augustowskim - prorządowym (zdecydowanie dominującym), republikańskim i elegijnym, pozostających odpowiednio pod patronatem Gajusza Cilniusza Mecenasa, Gajusza Azyniusza Polliona oraz Marka Waleriusza Messalli Korwina.

Profesor Julian Krzyżanowski pokazał, że kolejne epoki literackie zazwyczaj stoją wobec poprzednich w wyraźniej opozycji i często nawiązują do epok wcześniejszych. Na bazie skrupulatnej analizy epok literackich doby nowożytnej pokazał, że po epokach racjonalnych (antyk, odrodzenie, oświecenie, pozytywizm, dwudziestolecie międzywojenne), odwołujących się do wiedzy i rozumu, następują epoki irracjonalne (średniowiecze, barok, romantyzm, Młoda Polska), odwołujące się do wiary i uczucia ${ }^{12}$.

Opozycyjne położenie kolejnych epok literackich tworzy tzw. sinusoidę Krzyżanowskiego.

\footnotetext{
${ }^{11}$ Por. Stownik terminów literackich, red. Janusz SŁAwIŃSKI (Wrocław-Warszawa-Kraków: Zakład Narodowy im. Ossolińskich, 1998), 353-354.

12 Julian KRZYŻANOWSKI, „Barok na tle prądów romantycznych”, Przegląd Współczesny r. 16, t. 60, nr 178/179(1937). Pracę tę dwukrotnie przedrukowano: Julian KRZYŻANOwSKI, Od średniowiecza do baroku: Studia naukowo-literackie (Warszawa: Towarzystwo Wydawnicze „Rój”, 1938), s. 7-53; Henryk Markiewicz, red., Problemy teorii literatury w Polsce międzywojennej (Wrocław: Zakład Narodowy im. Ossolińskich, 1982), 287-320.
} 


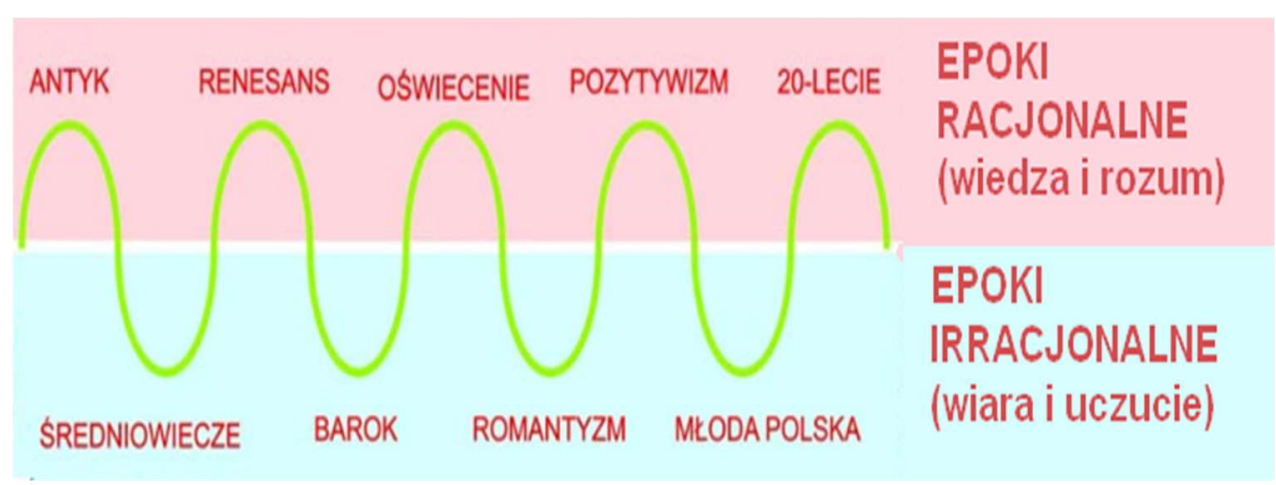

Ilustr. 1: Sinusoida prof. Juliana Krzyżanowskiego

Źródło: http://epooki-literackie.cba.pl/elsk.html

Wydaje się, że zaproponowaną przez Juliana Krzyżanowskiego teorię periodyzacji literatury, która pokazuje cykliczność zjawisk w dziedzinie kultury za pomocą sinusoidy, czyli matematycznej linii ciągłej o powtarzalnej amplitudzie, można $\mathrm{z}$ powodzeniem zastosować do nowego wydzielenia okresów literackich w literaturze rzymskiej.

\section{OKRES CYCEROŃSKI I OKRES AUGUSTOWSKI}

Za szczyt rozwoju literatury rzymskiej uchodzą w powszechnym mniemaniu 2 następujące po sobie okresy literackie (tzw. cyceroński i augustowski), które charakteryzują się swoistymi, wyraźnie opozycyjnymi cechami. Cechy te zostały zebrane w poniższej tabeli 2 .

\begin{tabular}{|l|l|}
\hline \multicolumn{1}{|c|}{$\begin{array}{c}\text { Cechy charakterystyczne literatury rzymskiej } \\
\text { okresu cycerońskiego }\end{array}$} & \multicolumn{1}{c|}{$\begin{array}{c}\text { Cechy charakterystyczne literatury rzymskiej } \\
\text { okresu augustowskiego }\end{array}$} \\
\hline 1. Dominacja prozy nad poezją. & 1. Dominacja poezji (epiki i liryki) nad prozą. \\
\hline $\begin{array}{l}\text { 2. Stworzenie rzymskiej prozy artystycznej. } \\
\text { Gruntowny rozwój wymowy. }\end{array}$ & $\begin{array}{l}\text { 2. Rzymska proza oraz wymowa (ograniczona do } \\
\text { deklamacji) są w zaniku. }\end{array}$ \\
\hline 3. Fascynacja retoryką i filozofią (grecką). & 3. Filozofia się nie rozwija. \\
\hline $\begin{array}{l}\text { 4. Szkoła poetycka „neoterycka” (poetae novi), } \\
\text { nawiązujaca do szkoły aleksandryjskiej epoki } \\
\text { hellenistycznej. }\end{array}$ & $\begin{array}{l}\text { 4. W poezji dominuje powrót do autorów kla- } \\
\text { sycznych (Homer, Hezjod, Safona, Alkajos). }\end{array}$ \\
\hline $\begin{array}{l}\text { 5. Powstanie pierwszych programów literackich. } \\
\text { 6. Powszechne zainteresowanie literaturą } \\
\text { i sztuką. }\end{array}$ & $\begin{array}{l}\text { 6. Wielość programów i ugrupowań literackich. } \\
\text { i sztuką. }\end{array}$ \\
\hline
\end{tabular}




\begin{tabular}{|l|l|}
\hline $\begin{array}{l}\text { 7. Rozwija się przekonanie Rzymian, że } \\
\text { dorównują Grekom w dziedzinie działalności } \\
\text { twórczej. }\end{array}$ & $\begin{array}{l}\text { 7. Utrwala się przekonanie Rzymian, że } \\
\text { dorównują Grekom w dziedzinie działalności } \\
\text { twórczej. }\end{array}$ \\
\hline $\begin{array}{l}\text { 8. Pesymizm i głęboki niepokój związany } \\
\text { z epoką burzliwych przemian, } \\
\text { poprzedzających upadek rzeczypospolitej } \\
\text { rzymskiej. }\end{array}$ & $\begin{array}{l}\text { 8. Wiara i ufność w odrodzenie narodowe } \\
\text { (tworzy się tzw. pax Romana) }\end{array}$ \\
\hline $\begin{array}{l}\text { 9. Polemiki literackie i światopoglądowe. } \\
\begin{array}{l}\text { 10. Rozwój biografistyki, genealogii oraz } \\
\text { studiów porównawczych. }\end{array}\end{array}$ & $\begin{array}{l}\text { 9. Polemiki literackie i światopoglądowe są } \\
\text { w zaniku (dominuje ideologia Augusta). }\end{array}$ \\
\hline
\end{tabular}

Tabela 2: Porównanie okresu cycerońskiego i augustowskiego

Źródło: opracowanie własne

Konfrontacja obu najbardziej reprezentatywnych okresów literackich antycznego Rzymu jasno pokazuje, że spośród dziesięciu wyróżnionych cech aż 8 (tj. 80\%) ma charakter zdecydowanie opozycyjny, a jedynie dwie cechy (oprócz wspomnianego już klasycznego języka łacińskiego) wykazują oczywistą kontynuację. Istotny jest problem granicy między tzw. okresem cycerońskim (okresem zmierzchu republiki) i okresem augustowskim ${ }^{13}$. Gdzie należy postawić cezurę? Czy na rok 44 przed Chr. (15 marca ginie Gajusz Juliusz Cezar) ${ }^{14}$ ? Czy na koniec 43 r. przed Chr. ( 7 grudnia śmierć z ręki siepaczy ponosi Marek Tulliusz Cyceron)? Czy raczej na rok 31 przed Chr., kiedy Oktawian August (wkrótce po bitwie pod Akcjum 2 września 31 r. przed Chr.)

${ }^{13} \mathrm{~W}$ niniejszym opracowaniu okres augustowski traktujemy jako fazę procesu historycznoliterackiego, zamykającą ostatecznie epokę republikańską, gdyż Oktawian August, który po bitwie po Akcjum (31 r. przed Chr.) i po śmierci Marka Antoniusza (1 sierpnia 30 r. przed Chr.) został wszechwładnym pryncepsem, zachował wszystkie elementy ustroju republikańskiego i podtrzymał iluzję funkcjonowania republiki rzymskiej. Termin „Die Augusteische Zeit” (w sensie historycznym) stosuje natomiast Michael vON ALBRECHT, Geschichte der römischen Literatur von Andronicus bis Beothius mit Berücksichtigung ihrer Bedeutung für die Neuzeit, t. I (München-New Providence-London-Paris: K.G. Saur, 1994²), 509-704, który w swoim podręczniku stara się omijać kwestię periodyzacji dziejów literatury rzymskiej.

${ }^{14}$ Warto podkreślić, że w literaturze włoskojęzycznej okres cyceroński bywa niekiedy nazywany okresem cezariańskim (wł. età cesariana, età di Cesare), por. Alessandro RonCONI, Letteratura latina pagana: profilo storico (Firenze: G.C. Sansoni, 1963), 40-46; Italo MARIOTTI, Storia e testi della letteratura latina, t. II: L'età di Cesare (Bologna: Zanichelli Editore, 1976). W niektórych publikacjach mamy dwojakie określenie okresu literackiego, np. „The Age of Cicero and Caesar", por. John Wight DufF, The Writers of Rome (Oxford: Oxford University Press, 1924), 29. Ten sam autor w innej pracy preferuje tradycyjny termin „The Ciceronian Period", zob. John Wight Duff, A Literary History of Rome. From the Origins to the Close of the Golden Age (London: Ernest Benn Limited, New York: Barnes \& Noble Inc 1953³), 202. 
staje się bezspornym jedynowładcą, realizującym własną, samodzielną politykę przy zachowaniu pozorów ustroju republikańskiego? A może za punkt graniczny należy uznać śmierć Marka Antoniusza (1 sierpnia 30 r. przed Chr.)? ${ }^{15}$ Osobiście przychylałbym się raczej do poglądu prof. Stanisława Stabryły. Tzw. epoka cycerońska nie zakończyła się wraz ze śmiercią Cycerona. W latach 43-35 przed Chr. swoje prace historyczne tworzy Gajusz Salustiusz Krispus (zm. 35 r. przed Chr.), działa czynnie też Tytus Pomponiusz Attyk (zm. 32 r. przed Chr.), swoje biografie pisze i publikuje Korneliusz Nepos (zm. po 27 r. przed Chr.), ważne dzieła encyklopedyczne i antykwaryczne pisze i ogłasza Marek Terencjusz Warron (zm. 27 r. przed Chr.), w tym także zachowane dzieło Res rusticae (wydane w 37 r. przed Chr.). Kontynuują swoją działalność twórczą młodsi wiekiem neoterycy, np. Publiusz Terencjusz Warron z Ataksu (ur. 82 r. przed Chr.), tworzący pod koniec życia poemat epicki Argonautae, a wśród poetów wciąż prym wiedzie nestor i główny reprezentant Waleriusz Katon, zwany łacińską syreną (Latina Siren), który zgodnie z przekazaną tradycją był twórcą i głównym promotorem ideologii neoteryckiej, towarzyszem i takim nauczycielem (grammaticus), który „zbiera i tworzy poetów" (qui legit et facit poetas) ${ }^{16}$. Główny poeta epicki epoki augustowskiej Publiusz Wergiliusz Maron (70-19 przed Chr.) pisze swoje prace młodzieńcze (w tym słynny poemat pasterski o komarze pt. Culex ${ }^{17}$ ) w duchu poetów Młodego Rzymu. Również wydane w roku 39 i ponownie (w wersji rozszerzonej) w roku 37 Bukoliki (łac. Eclogae) ciągle jeszcze pozostają pracą na wskroś neoterycką. Dopiero następne dzieło Wergiliusza pt. Georgiki (łac. Georgica), ukończone i wydane w 29 r. przed Chr. po 7 latach starannej pracy, stanie się prawdziwym zarzewiem nowego okresu literackiego zwanego augustowskim. Zatem na podstawie twórczości Wergiliusza okres przełomu możemy datować

${ }^{15} \mathrm{~W}$ niektórych opracowaniach encyklopedycznych pada niekiedy niespójna lub wręcz rozbieżna odpowiedź co do granic chronologicznych okresu cycerońskiego i augustowskiego, por. choćby The Oxford Companion to Classical Literature, red. Margaret C. HowATSON (Oxford-New York: Oxford University Press, $1989^{2}$ ), 79, s.v. Augustean age: „It spans roughly the time from the assassination of Julius Caesar in 44 BC to the death of Ovid in AD 17 (Augustus died in AD 14)"; s. 134, s.v. Ciceronian age: „a term sometimes used to signify the period in Latin literature that roughly coincided with the manhood of Cicero and the last years of the republic, about 70 to 30 BC".

${ }^{16}$ Jürgen BLÄNSDORF, Fragmenta poetarum Latinorum epicorum et lyricorum praeter Ennium et Lucilium (Stutgardiae et Lipsiae: B.G. Teubner, 1995), 200.

${ }^{17}$ Przekazy antyczne zgodnie podają, że Wergiliusz napisał żartobliwy epyllion Culex w wieku 16 lat, tj. około 54 r. przed Chr. Nie widzę żadnego powodu, by podważać autorstwo Wergiliusza lub wczesną datę powstania utworu. Istnieje jednak spora grupa uczonych wyrażających odmienne poglądy. Co do tej problematyki, zob. CyTOWSKA, SzELEST, Literatura rzymska. Okres augustowski, 47-51. 
na lata $37-29^{18}$. Na te lata przypada zatem cezura między okresem cycerońskim i augustowskim. Kwintus Horacjusz Flakkus (65-8 r. przed Chr.), najwybitniejszy twórca liryczny epoki augustowskiej, do koła poetyckiego Mecenasa trafia na początku 37 r. przed Chr., jednak dopiero w roku 30 wychodzą drukiem jegoż Epody oraz Satyry, które są wyznacznikami zupełnie nowego kierunku literackiego w zakresie liryki rzymskiej. I tu cezura między dwoma okresami literackimi wydaje się przypadać gdzieś między 37 a 30 r. przed Chr.

Profesor Stanisław Stabryła sugeruje, że rok 31 przed Chr. (data bitwy pod Akcjum) powinien być uznany za koniec okresu zmierzchu republiki ( $\mathrm{tj}$. okresu cycerońskiego) i jednocześnie za początek nowego okresu literackiego zwanego augustowskim. Istotnie, pierwsze znamienne (tj. literacko nowatorskie) publikacje dwóch głównych reprezentantów nowej epoki literackiej, tj. Horacego i Wergiliusza, przypadające odpowiednio na rok 30 i 29 przed Chr., zdecydowanie wzmacniają tezę krakowskiego filologa klasycznego. Należy jednak pamiętać, że dominujący nurt literatury rzymskiej zrodził się w latach trzydziestych ery przedchrześcijańskiej, a zakończył niedługo po śmierci Oktawiana Augusta (zm. 14 r. po Chr.). Ostatni wielki twórca okresu augustowskiego Publiusz Owidiusz Nazon (43 r. przed Chr. - 18 r. po Chr.) umiera bowiem 4 lata później, a wraz z nim kończy się ,złota era” rzymskiej elegii miłosnej ${ }^{19}$.

\section{RAMY CHRONOLOGICZNE TZW. OKRESU CYCEROŃSKIEGO}

W poprzednim rozdziale przychyliśmy się do zdania Stanisława Stabryły, że koniec okresu literackiego zwanego popularnie cycerońskim przypada na późne lata trzydzieste ostatniego stulecia ery przedchrześcijańskiej (a nie na rok śmieci Marka Tulliusza Cycerona, tj. 43 przed Chr.).

Należy się teraz zastanowić nad początkiem okresu literackiego określonego mianem cycerońskiego (względnie okresem zmierzchu republiki). Czy

${ }^{18}$ Należy odnotować, że Mieczysław BROżEK (Historia literatury łacińskiej w starożytności. Zarys (Wrocław-Warszawa-Kraków: Zakład Narodowy im. Ossolińskich, 1969)), oprócz okresu cycerońskiego („Od Sulli do upadku republiki w roku 42 p.n.e.”, 137-231) i okresu augustowskiego („Pryncypat Augusta”, 271-352), wydziela także okres przejściowy („Między republiką a pryncypatem”, 232-270). Z punktu widzenia periodyzacji literatury wydzielanie okresu przejściowego wydaje się nieuzasadnione.

${ }^{19}$ Prof. Lewandowski umieszcza okres augustowski w latach 40 r. przed Chr. -20 r. po Chr. zaraz po okresie cycerońskim (80-40 r. przed Chr.), ale nie uzasadnia wyboru lat granicznych, por. Ignacy LewANDowski, Historiografia rzymska (Poznań: Wydawnictwo Poznańskie, 2007), 168. 
przypada on na rok 81/80 przed Chr., tj. czas pierwszych wystąpień publicznych Cycerona? Czy jego początek należy cofnąć aż do roku 133 przed Chr., jak sugeruje prof. S. Stabryła. Wydaje się, że tradycyjny pogląd jest bliższy prawdy. Dlaczego? Otóż w okresie cycerońskim tworzy się nowe wiodące ugrupowanie poetyckie, zbierające głównie poetów z Galii przedalpejskiej, tzw. poetae novi, zwani z grecka neoterykami. Na czele tego ugrupowania literackiego stanął Publiusz Waleriusz Katon (ok. 98 - po 35 r. przed Chr.), który skupił wokół siebie innych rówieśnych i młodszych poetów. Najwybitniejszym przedstawicielem neoteryków okazał się Gajusz Waleriusz Katullus rodem z Werony (87-54 r. przed Chr.), dla którego natchnieniem stała się piękna Klodia, nazywana w jego wierszach Lesbią, która prawdopodobnie była (w latach 63-59 przed Chr.) żoną Kwintusa Cecyliusza Metellusa Celera. Nie ulega żadnej wątpliwości, że rozkwit poezji neoteryckiej mógł nastąpić dopiero po śmierci Sulli (78 r. przed Chr.), kiedy nastąpiła normalizacja stosunków w Rzymie i kiedy dojrzałość twórczą osiągnęli najstarsi wiekiem poetae novi. Cyceron (106-43 r. przed Chr.), będąc starszy wiekiem od większości neoteryków, nie przyswoił sobie zasad poezji neoteryckiej i nie potrafił bezstronnie ocenić jej wartości. Neoterycy byli w jego opinii „śpiewakami spod znaku Euforiona" (cantores Euphorionis). Ruch ten był wiodący w zakresie liryki i epiki w okresie cycerońskim. Podążali za nim także twórcy młodszego pokolenia, m.in. Korneliusz Gallus (70-26 r. przed Chr.), a także Publiusz Wergiliusz Maron (70-19 r. przed Chr.) w początkach swojej twórczości (co najmniej do roku 37 przed Chr.). Nie wydaje się zatem możliwe, żeby początki ruchu neoteryckiego, którego bezpośrednim rezultatem była kreacja nowego okresu literackiego zwanego cycerońskim (lub okresem zmierzchu republiki), można było przesunąć na lata wcześniejsze niż rok 81 przed Chr.

Także aspekt historyczny nie jest dostatecznie przekonujący. Zmierzch republiki rzymskiej bynajmniej nie wiąże się z reformami ustrojowymi, które usiłowali przeprowadzić w sposób legalny, tj. zgodny z obowiązującym wówczas prawem, bracia Tyberiusz i Gajusz Semproniusze Grakchowie. Zagrożeniem dla istniejącego ustroju republikańskiego stały się dopiero krwawe walki optymatów i popularów w latach osiemdziesiątych I wieku (88-82 r. przed Chr.). Obie partie, a szczególnie stojące na ich czele jednostki, dążyły do przejęcia władzy absolutnej w Rzymie nie zawsze legalnymi środkami. Efektem tych dążeń były wojny domowe, proskrypcje, konfiskaty majątków, których ofiarami padali zarówno optymaci, jak i członkowie stronnictwa 
popularów. Rządy dyktatorskie Lucjusza Korneliusza Sulli (82-79 r. przed Chr.) stanowią ukoronowanie krwawego dziesięciolecia.

Ostatecznie opowiadam się za datacją tzw. okresu cycerońskiego na lata 81-31 przed Chr.

\section{CZY EPOKA ARCHAICZNA BYŁA JEDNOLITA LITERACKO?}

Za początek literatury rzymskiej uważa się wystawienie przez Liwiusza Andronika pierwszej komedii (fabula palliata) i pierwszej tragedii (fabula cothurnata) w Rzymie w roku 240 przed Chr. Z kolei umowny kraniec epoki archaicznej (81/80 r. przed Chr.) wiąże się z pierwszymi wystąpieniami Marka Tulliusza Cycerona (106-43 r. przed Chr.) na arenie publicznej. Tradycyjny „okres archaiczny” trwa zatem przez około 160 lat, czyli trzykrotnie dłużej niż okres cyceroński (ok. 50 lat) i niemal czterokrotnie dłużej niż okres augustowski (ok. 44 lata). Warto zastanowić się nad pytaniem postawionym w tej części artykułu: Czy tak długo trwająca epoka archaiczna była literacko jednolita?

Odpowiedź na powyższe pytanie wydaje się oczywista. Epoka archaiczna nie ma spójnego charakteru i dość wyraźnie dzieli się na 2 zdecydowanie opozycyjne okresy ${ }^{20}$. W pierwszym etapie, który moglibyśmy nazwać „okresem hellenizującym" lub okresem wczesnoarchaicznym (240-160 r. przed Chr.), mamy do czynienia z powszechną fascynacją literaturą grecką, która prowadzi do gruntownej adaptacji helleńskich gatunków epickich, lirycznych i dramatycznych. W tym okresie działalność literacką w języku łacińskim prowadzą przede wszystkim wybitni twórcy pochodzący spoza Rzymu: Grek rodem z Tarentu - Liwiusz Andronik (ok. 284 - ok. 204 r. przed Chr.), Kampańczyk z Kapui - Gnejusz Newiusz (zm. 201 r. przed Chr.), Umbryjczyk z Sarsiny - Tytus Makcjusz Plaut (ok. 250 - ok. 184 r. przed Chr.), Kalabryjczyk rodem z messapijskiego miasta Rudiae - Kwintus Enniusz (239169 r. przed Chr.), pochodzący z Galii Przedalpejskiej - Cecyliusz Stacjusz (ok. 230 - ok. 168 r. przed Chr.) czy komediopisarz rodem z Kartaginy Publiusz Terencjusz Afer (ok. 190 - ok. 159 r. przed Chr.). W okresie

\footnotetext{
${ }^{20}$ Por. RYCHLEWSKA, CYTOWSKA, SzELEST, Literatura rzymska. Okres archaiczny, 207. W tej pracy okres archaiczny został podzielony na dwie części (z cezurą przypadającą na rok 160 przed Chr.). Autorki zatem osobno omawiają „literaturę rzymską w latach 160-80 p.n.e.” (207-362). Należy odnotować, że niektórzy autorzy rzymscy (Katon, Terencjusz) zostali niewłaściwie ulokowani w wydzielonych przez autorki fazach rozwojowych literatury rzymskiej, por. przypisy 18 i 19.
} 
późnoantycznym (160-80 r. przed Chr.) na plan pierwszy wysuwają się rodowici Rzymianie ${ }^{21}$.

Wczesna historiografia rzymska, począwszy od Fabiusza Piktora (III wiek przed Chr.), używa wyłącznie języka greckiego. Za wzorem Piktora tak postępują inni dawni historycy: Lucjusz Cyncjusz Alimentus, Gajusz Acyliusz, Aulus Postumiusz Albinus, Publiusz Korneliusz Scypion ${ }^{22}$. W drugim etapie następuje zdecydowana reakcja elit rzymskich wobec tendencji filhelleńskich. Marek Porcjusz Katon (234-149 r. przed Chr.), przywódca opcji antygreckiej, pod koniec życia (zapewne po 160 r. przed $C h r .{ }^{23}$ ) stworzył pierwszą historię Rzymu napisaną w języku łacińskim pt. Origines, która została doprowadzona do czasów mu współczesnych (tj. do roku 149).

$\mathrm{Za}$ umowną granicę między oboma okresami może uchodzić rok 160 przed Chr., kiedy w senacie rzymskim zapadła decyzja o wygnaniu obcych (głównie greckich) filozofów i retorów z miasta Rzymu. Wtedy znika ze sceny literackiej komediopisarz Publiusz Terencjusz Afer ${ }^{24}$, a głównym reprezentantem nowego okresu zostaje wiekowy już Marek Porcjusz Katon, autor pierwszej rzymskiej encyklopedii pt. Praecepta ad filium i pierwszej łacińskojęzycznej historii Rzymu ${ }^{25}$. Jego kolejne dzieło De agri cultura jest

${ }^{21} \mathrm{~W}$ literaturze przedmiotu spotykamy także inne próby dzielenia literatury rzymskiej doby republiki. BROżEK (Historia literatury, 100-136), wydziela okres przejściowy „od Grakchów do Mariusza i Sulli”. Podobnie postępuje Ludwika RYCHLEWSKA (Dzieje literatury rzymskiej (Wrocław: Wydawnictwo Uniwersytetu Wrocławskiego, 2005)), która daje 3 nierównej wielkości rozdziały: „Literatura Rzymu republikańskiego” (23-74), „Rozwój literatury od Grakchów do Mariusza i Sulli” (75-82) oraz „Literatura czasów Cycerona” (83-130).

${ }^{22}$ Lewandowski, Historiografia rzymska, 33-38; Denis Feeney, Beyond Greek. The Beginnings of Latin Literature (Cambridge, MA-London: Harvard University Press, 2016), 173-176. Uważa się niekiedy, że wczesna historiografia rzymska kierowała się celem propagandowym. Dzieła dotyczące historii Rzymu byłyby kierowane do odbiorców greckich jako przeciwwaga dla antyrzymskiej historiografii kartagińskiej pisanej po grecku. Niezależnie od faktycznych motywów, którymi kierowali się w swoich poczynianiach historycy rzymscy okresu wczesnoarchaicznego, skłonność do pisania po grecku pokazuje ich postawę filhelleńską.

${ }^{23}$ Herbert MYŚliwiec („Cato”, w Anna ŚwiderkównA, red., Stownik pisarzy antycznych (Warszawa: Wiedza Powszechna, 1982), s. 130), podaje, że Katon „w starości, ok. 168, przystąpił [...] do opracowania dziejów Rzymu, które doprowadził do 149”. Nie ulega zatem wątpliwości, że dzieło Origines ukazało się pośmiertnie (tj. po roku 149 przed Chr.).

${ }^{24}$ Publiusz Terencjusz Afer wystawiał swoje komedie w latach 166-160 przed Chr., zob. Ewa SKWARA, Historia komedii rzymskiej (Warszawa: Prószyński i S-a, 2001), 49, 110; EADEM, Komedia wedlug Terencjusza (Warszawa-Toruń: Fundacja na Rzecz Nauki Polskiej, 2016), 54. Nie ulega zatem wątpliwości, że twórczość literacka Terencjusza przypada na schyłek archaicznego okresu „hellenizującego”, a nie na okres następny „reakcji antygreckiej” (160-80 r. przed Chr.). Inaczej jednak ów komediopisarz jest klasyfikowany w podręczniku: RYCHLEWSKA, CYTOWSKA, SZELEST, Literatura rzymska. Okres archaiczny, 217-281.

${ }^{25}$ Jak podaje Korneliusz Nepos (Cato 3), Marek Porcjusz Katon Starszy dopiero w bardzo zaawansowanym wieku przystąpił do intensywnej twórczości literackiej. Katon napisał swoje 
pierwszym rzymskim traktatem agronomicznym ${ }^{26}$, opartym na własnym doświadczeniu autora, ale odwołującym się (choć w niewielkim stopniu) do obcej literatury agronomicznej. Literaturę historyczną w języku łacińskim kontynuują inni autorzy, tworzący w drugiej połowie II wieku przed Chr. i w dwu pierwszych dekadach I wieku przed Chr. W późnoantycznym okresie „reakcyjnym" działa satyryk Gajusz Lucyliusz (ok. 180 - ok. 103 r. przed Chr.), podejmujący tematykę wyłącznie rzymską, a także grupa epigramatyków na czele z Kwintusem Lutacjuszem Katulusem (ok. 150-87 r. przed Chr.), konsulem ze 102 r. Epigramatycy rzymscy okresu późnoarchaicznego (Waleriusz Edituus, Porcjusz Licinus, Lutacjusz Katulus) reprezentują niezależną grupę poetycką ${ }^{27}$, która tworzy samodzielne utwory, stojące w wyraźnej opozycji do domniemanego greckiego źródła. Pojawiają się w tym czasie poetyckie dyskusje dotyczące literatury rzymskiej, między innymi w sprawie ważności poszczególnych komediopisarzy rzymskich i wartości ich dorobku (Liber de poetis Wolkacjusza Sedigitusa). Rozwija się epistolografia, rozkwita retoryka i wymowa. Oprócz Katona w tej ostatniej dziedzinie wybija się między innymi Gajusz Leliusz, Scypion Afrykański Młodszy, a nadto obaj bracia Grakchowie ${ }^{28}$, którzy swoją edukację zawdzięczają matce Kornelii, córce Scypiona Afrykańskiego. W literaturze przedmiotu jest ona słusznie nazywana „matką epistolografii łacińskiej”29.

Około roku 160 przed Chr. rodzi się zatem okres literacki wyraźnie opozycyjny w stosunku do archaicznego okresu „hellenizującego” (240-160 r. przed Chr.). Następuje wtedy gwałtowny zwrot od przesadnego filhellenizmu

najważniejsze dzieła (Origines, Praecepta ad filium, De agri cultura) w latach 168-149 przed Chr. Pod koniec życia ogłosił też drukiem mowy sądowe i polityczne. Zatem Katona musimy traktować jako reprezentanta późnoarchaicznego okresu literackiego (,reakcji antygreckiej”), a nie jako reprezentanta poprzedniej fazy rozwojowej literatury rzymskiej. Inaczej jednak postępują RYCHLEWSKA, CYTOWSKA, SzELEST, Literatura rzymska. Okres archaiczny, 186-204. O stosunku Katona do kultury greckiej, zob. Sylwia SzCZYGIEt, Marek Porcjusz Katon: rzymski tradycjonalista czy polityk realista (Warszawa: Wydawnictwo DiG, 2011), 148-155.

${ }^{26}$ Zob. Ireneusz MikoŁAJczYK, Rzymska literatura agronomiczna (Toruń: Wydawnictwo Uniwersytetu Mikołaja Kopernika, 2004), 26-51.

${ }^{27}$ Por. Augusto Rostagni, Storia dela letteratura latina, t. I: La repubblica (Torino: Unione Tipografico-Editrice Torinense, 1954), 311-316; Hanna SzELEST, „Epigram rzymski okresu archaicznego", Meander 58 nr 3-4(2003): 305-318.

${ }^{28}$ O licznych mówcach rzymskich epoki archaicznej szerzej rozprawia Marek Tulliusz Cyceron, por. CyCERon, Brutus, czyli o sławnych mówcach, przełożyła, wstępem i przypisami opatrzyła Magdalena NowAK (Warszawa: Prószyński i S-ka, 2008), 80-100.

${ }^{29}$ Aurora LÓPEZ LÓPEZ, „Cornelia, madre de la epistolografia latina”, w Agustín RAMOs GuERREIRA, red., Mnemosynum C. Codoñer a discipulis oblatum (Salamanca: Ediciones Universidad Salamanca, 1991), 161-173; Corrado Petrocelli, „Cornelia, la matrona”, w Augusto FraschetTI, red., Roma al femminile (Roma: Editori Laterza, 1994), 21-70. 
do tematyki czysto rzymskiej. W Rzymie rozwija się dramat o tematyce rzymskiej lub italskiej (fabula togata, fabula tabernaria, fabula praetexta, fabula Atellana $)^{30}$, którego głównymi przedstawicielami są: Tytyniusz ${ }^{31}$, Lucjusz Afraniusz, Kwinkcjusz Atta (łac. Quinctius Atta). W historiografii rzymskiej język łaciński całkowicie usuwa w cień język grecki. W tym okresie tworzą się już ugrupowania poetyckie, skupiające rzymskich poetówepigramatyków, którzy preferują tematykę erotyczną, a dystych elegijny staje się najbardziej optymalną miarą wierszową rzymskiej poezji miłosnej. W tym właśnie czasie przejęty od Greków heksametr daktyliczny (wprowadzony do rzymskiej epiki przez Enniusza) zdobywa tak wyraźną przewagę nad tradycyjnym metrum saturnijskim, że stosowany przez Liwiusza Andronika i Gnejusza Newiusza versus Saturnius ostatecznie zanika gdzieś u schyłku II wieku przed $\mathrm{Chr}^{32}$

Warto w tej sytuacji postawić pytanie: Czy archaiczny okres „hellenizujący” (240-160 r. przed Chr.) i późnoarchaiczny okres „reakcyjny” (160-80 r. przed Chr.) stoją wobec siebie w podobnej opozycji, jak okres cyceroński w stosunku do okresu augustowskiego? Niewątpliwie tak. Łatwo się o tym przekonać, porównując $\mathrm{w}$ postaci tabelarycznej typowe cechy obu postulowanych okresów:

\begin{tabular}{|l|c|}
\hline $\begin{array}{c}\text { Cechy charakterystyczne literatury rzymskiej } \\
\text { okresu „hellenizującego” (archaicznego) }\end{array}$ & $\begin{array}{c}\text { Cechy charakterystyczne literatury rzymskiej } \\
\text { okresu „reakcyjnego” (późnoarchaicznego) }\end{array}$ \\
\hline $\begin{array}{l}\text { 1. Głęboka fascynacja Rzymian kulturą } \\
\text { i umysłowością helleńską, wyrażająca się } \\
\text { adaptacją homeryckiej epiki i greckiej }\end{array}$ & $\begin{array}{c}\text { 1. Oficjalne odrzucenie filhellenizmu } \\
\text { i niezgodnych z duchem rzymskim } \\
\text { sztuki dramatycznej. }\end{array}$ \\
$\begin{array}{l}\text { elementów kultury greckiej; wygnanie } \\
\text { filozofów i retorów obcych z Rzymu } \\
\text { (160 r. przed Chr.). }\end{array}$ \\
\hline
\end{tabular}

${ }^{30} \mathrm{~W}$ literaturze przedmiotu podkreśla się, że komedia o tematyce rzymskiej „powstala poniekąd jako reakcja przeciwko postępującej hellenizacji życia Rzymian w II w. p.n.e.”, zob. Lucyna StANKIEwICZ, Komedia Lucjusza Afraniusza i jej zwiazki z innymi odmianami komedii (Wrocław: Wydawnictwo Uniwersytetu Wrocławskiego, 1999), 9.

${ }^{31}$ Zob. Lucyna STANKIEWICZ, Tytyniusz - przedstawiciel komedii rzymskiej zwanej 'fabula togata' (Wrocław: Wydawnictwo Uniwersytetu Wrocławskiego, 1987).

${ }^{32}$ Zwykle przytacza się świadectwo Horacego (Ep. II 1, w. 157-160) jako dowód używania wiersza saturnijskiego przez lud rzymski w epoce augustowskiej. Poeta jednak wyraźnie stwierdza, że szorstki wiersz saturnijski odszedł w zapomnienie (w. 157-158: horridus ille / defluxit numerus Saturnius), ale jednocześnie dodaje, że współczesna poezja rzymska wykazuje typowe dla wsi niedoskonałości wersyfikacyjne. Zob. Kwintus Horacıusz FlaKkus, Dzieła wszystkie, t. II, tekst łaciński do druku przygotował, wyboru przekładów dokonał, przedmową, życiorysem poety, wersyfikacją i komentarzem opatrzył Oktawiusz JUREWICZ (Wrocław: Ossolineum, 1986), 382-383. 


\begin{tabular}{|c|c|}
\hline $\begin{array}{l}\text { 2. Adaptacja epickich arcydzieł literatury } \\
\text { greckiej (np. Odusia Liwiusza Andronika). } \\
\text { Powstanie pierwszych epopei rodzimych } \\
\text { (Bellum Poenicum Newiusza, Annales } \\
\text { Enniusza). } \\
\end{array}$ & $\begin{array}{l}\text { 2. Tendencja do tworzenia rodzimych eposów } \\
\text { o tematyce rzymskiej (Aulus Hostiusz, } \\
\text { Furiusz z Ancjum), jak i adaptacji dzieł } \\
\text { greckich (Ilias Gnejusza Macjusza, Ilias } \\
\text { Niniusza Krassusa). }\end{array}$ \\
\hline $\begin{array}{l}\text { 3. Wśród gatunków dramatycznych } \\
\text { zdecydowanie dominuje komedia } \\
\text { o tematyce greckiej (fabula palliata), } \\
\text { uprawiana m.in. przez Plauta, Cecyliusza } \\
\text { Stacjusza i Terencjusza. }\end{array}$ & $\begin{array}{l}\text { 3. Zwrot ku gatunkom dramatycznym } \\
\text { o tematyce typowo rzymskiej lub italskiej } \\
\text { (fabula Atellana, fabula praetexta, fabula } \\
\text { togata, fabula tabernaria), co owocuje } \\
\text { rozwojem komedii narodowej (Tytyniusz, } \\
\text { Lucjusz Afraniusz, Kwinkcjusz Atta). }\end{array}$ \\
\hline $\begin{array}{l}\text { 4. W poezji rzymskiej (tj. w liryce, epice } \\
\text { i dramacie) przeważają wątki } \\
\text { charakterystyczne dla literatury greckiej. }\end{array}$ & $\begin{array}{l}\text { 4. W poezji dominuje satyra polityczna } \\
\text { o tematyce typowo rzymskiej (G. Lucyliusz, } \\
\text { ok. } 180 \text { - ok. } 103 \text { r. przed Chr.) }\end{array}$ \\
\hline $\begin{array}{l}\text { 5. Brak sformalizowanych programów } \\
\text { i ugrupowań literackich. }\end{array}$ & $\begin{array}{l}\text { 5. Powstanie pierwszych grup literackich, np. } \\
\text { koła epigramatyków (między innymi } \\
\text { Waleriusz Edituus, Porcjusz Licinus), } \\
\text { skupionego wokół Kwintusa Lutacjusza } \\
\text { Katulusa (ok. } 150-87 \text { r. przed Chr.), konsula } \\
\text { z } 102 \text { r. przed Chr. }\end{array}$ \\
\hline $\begin{array}{l}\text { 6. Pierwsi historycy rzymscy opisują dzieje } \\
\text { Rzymu w języku greckim (tak postępują } \\
\text { m.in. Kwintus Fabiusz Piktor, Lucjusz } \\
\text { Cyncjusz Alimentus, Korneliusz Scypion, } \\
\text { Gajusz Acyliusz, Aulus Postumiusz } \\
\text { Albinus). }\end{array}$ & $\begin{array}{l}\text { 6. Historia Rzymu jest opisywana w języku } \\
\text { łacińskim (począwszy od Origines Marka } \\
\text { Porcjusza Katona, wydanych po } 149 \text { r. przed } \\
\text { Chr.). Jego śladami podążają historycy } \\
\text { młodszego pokolenia: L. Kasjusz Hemina, } \\
\text { Gn. Gelliusz, L. Celiusz Antypater, G. } \\
\text { Semproniusz Tuditanus, Semproniusz } \\
\text { Asellion i inni. }\end{array}$ \\
\hline $\begin{array}{l}\text { 7. Poszukiwanie inspiracji w literaturze i } \\
\text { retoryce greckiej. }\end{array}$ & $\begin{array}{l}\text { 7. Tworzenie nowych gatunków literackich } \\
\text { (satyra rzymska) i rozwijanie rodzimych } \\
\text { wątków i tematów. }\end{array}$ \\
\hline $\begin{array}{l}\text { 8. Stabilizacja państwa rzymskiego po } \\
\text { pierwszej wojnie punickiej, zakończonej } \\
\text { zwycięsko w } 241 \text { r. przed Chr. }\end{array}$ & $\begin{array}{l}\text { 8. Walki klasowe i polityczne, między innymi } \\
\text { w epoce braci Grakchów (133-121 r. } \\
\text { przed Chr.) i w epoce mariańskiej ( } 88-83 \text { r. } \\
\text { przed Chr.). }\end{array}$ \\
\hline $\begin{array}{l}\text { 9. Twórczość literacką uprawiają głównie } \\
\text { autorzy obcy przybyli do Rzymu z zewnątrz } \\
\text { (m.in. Liwiusz Andronik, Newiusz, } \\
\text { Enniusz, Plaut, Cecyliusz Stacjusz, } \\
\text { Terencjusz). }\end{array}$ & $\begin{array}{l}\text { 9. Wzrost zainteresowania rzymskich } \\
\text { patrycjuszy literaturą piękną (np. G. Lucy- } \\
\text { liusz, Kw. Lutacjusz Katulus) oraz } \\
\text { rzymskich kobiet retoryką i epistolografią } \\
\text { (Kornelia, matka Grakchów). }\end{array}$ \\
\hline $\begin{array}{l}\text { 10. Tworzenie się literackiego języka } \\
\text { łacińskiego. }\end{array}$ & $\begin{array}{l}\text { 10. Gruntowny rozwój wymowy i retoryki } \\
\text { rzymskiej (m.in. Katon, Scypion Młodszy, } \\
\text { bracia Grakchowie, Leliusz). }\end{array}$ \\
\hline
\end{tabular}

Tabela 3: Porównanie okresu archaicznego i późnoarchaicznego Źródło: opracowanie własne 
Zestawienie wyróżnionych w tabeli 3 cech literatury rzymskiej antycznego okresu „hellenizującego" i okresu „reakcyjnego” wskazuje jednoznacznie, że w obrębie epoki antycznej musimy wyróżnić dwie opozycyjne fazy historycznoliterackie, czyli 2 odrębne okresy literackie. Co więcej, łatwo można wykazać, że epoka cycerońska (która przybliża Rzymianom naukę i filozofię grecką zarówno w postaci eposów dydaktycznych, dialogów i rozpraw filozoficznych) pod wieloma względami nawiązuje do okresu wczesnoarchaicznego („hellenizującego"), podczas gdy epokę augustowską z okresem późnoarchaicznym („reakcyjnym”) łączy głębokie zamiłowanie do tradycji rodzimych oraz do tematyki czysto rzymskiej. Dokładne te same koneksje i relacje można dostrzec $\mathrm{w}$ dobie współczesnej między epokami racjonalnymi (odrodzenie $\rightarrow$ oświecenie $\rightarrow$ pozytywizm itd.) i epokami irracjonalnymi (średniowiecze $\rightarrow$ barok $\rightarrow$ romantyzm $\rightarrow$ Młoda Europa etc.).

Zagadnienie periodyzacji literatury rzymskiej doby cesarstwa w niniejszej rozprawce nie zostało podjęte $z$ uwagi na ograniczenia dotyczące objętości artykułów naukowych. W najbliższej przyszłości autor zamierza wykazać, że literatura rzymska epoki cesarstwa daje się podzielić na 5 odrębnych faz historycznoliterackich.

\section{KONKLUZJE}

Podsumujmy krótko nasze dotychczasowe rozważania. Literatura rzymska doby republiki dzieli się na 4 dobrze wyodrębnione okresy literackie:

1. Okres archaiczny albo „hellenizujący” (240-160 r. przed Chr.);

2. Okres późnoarchaiczny albo „reakcyjny” (160-81 r. przed Chr.);

3. Okres cyceroński albo okres ,zmierzchu republiki” (81-31 r. przed Chr.);

4. Okres augustowski (31 r. przed Chr. -14 r. po Chr.).

Poszczególne okresy literackie stoją w wyraźnej opozycji do faz poprzedzających i po nich następujących. Występują w nich dominujące prądy, odmienne w każdej fazie historycznoliterackiej, wyznaczane przez wiodące ugrupowania bądź koła literackie. Biorąc pod uwagę stosunek Rzymian do dorobku kulturalnego Hellenów, możemy łatwo dojść do konkluzji, że okresy nieparzyste $(1,3)$ mają charakter wyraźnie prohelleński, co przejawia się między innymi w tłumaczeniu bądź adaptacji najważniejszych dzieł literatury greckiej, wykorzystaniu istniejących w Grecji rodzajów i gatunków literackich, przyswojeniu obcych struktur metrycznych, motywów literackich lub nurtów filozoficznych, podczas gdy w okresach parzystych $(2,4)$ literatura 
rzymska wprowadza rodzimą tematykę, rozwija własne gatunki literackie (np. satyrę rzymską) oraz podejmuje rywalizację na polu dramatu, epiki i liryki. Można z powodzeniem sądzić, że rozwój literatury rzymskiej w dobie republiki (a następnie cesarstwa), ujmowany w oparciu o kryterium rodzimości i wpływów obcych ${ }^{33}$, przebiega zgodnie z wykresem sinusoidy.

Sinusoida okresów literackich, wyróżnionych w dziejach literatury łacińskiej doby republiki rzymskiej (zob. ilustr. 2), przecina oś czasu w następujących punktach: [1] 240 r. przed Chr.; [2] 160 r. przed Chr.; [3] 81 r. przed Chr.; [4] 31 r. przed Chr.; [5] 14 r. po Chr.

Ilustr. 2. Sinusoida okresów literackich doby republiki rzymskiej i wczesnego cesarstwa opracowana według kryterium helleńskości lub rodzimości twórczości literackiej

Okresy nieparzyste 1, 3,5 - odwołujące się do myśli i dorobku greckiego Okresy parzyste 2, 4, 6 - rozwijające tradycje rodzime, typowo rzymskie



Źródło: opracowanie własne

${ }^{33}$ Należy zauważyć, że „najczęstszą podstawą podziału” literatury na okresy (epoki) literackie w XIX stuleciu był „stosunek między rodzimością a wpływami obcymi” lub „dominowanie w niej określonej postawy duchowej czy światopoglądowej”, a następnie charakterystyczne ,prądy literackie”, por. Henryk MARKIEWICZ, „Próba periodyzacji nowożytnej literatury polskiej”, w: IDEM, Przekroje i zblizenia dawne i nowe. Rozprawy i szkice z wiedzy o literaturze (Warszawa: Państwowy Instytut Wydawniczy, 1976), s. 7. W powyższych rozważaniach zastosowano kryteria kombinowane. 
Fazy rozwojowe języka łacińskiego zasadniczo pokrywają się z periodyzacją dziejów literatury rzymskiej. W obrębie epoki archaicznej, wyróżnionej na podstawie czynników historycznojęzykowych, wyróżniamy dwie opozycyjne fazy, mianowicie archaiczny okres „hellenizujący” (240-160 r. przed Chr.) i późnoarchaiczny okres „reakcyjny” (160-81 r. przed Chr.). Także epoka klasyczna, zwana niekiedy epoką złotej łaciny, składa się z dwóch przeciwstawnych okresów literackich: cycerońskiego i augustowskiego, czego od dawna byliśmy świadomi ${ }^{34}$.

\section{BIBLIOGRAFIA}

AlBReCht, Michael von. Geschichte der römischen Literatur von Andronicus bis Beothius mit Berücksichtigung ihrer Bedeutung für die Neuzeit, t. I, München-New Providence-LondonParis: K.G. Saur, $1994^{2}$.

BläNSDORF, Jürgen. Fragmenta poetarum Latinorum epicorum et lyricorum praeter Ennium et Lucilium. Stutgardiae et Lipsiae: B.G. Teubner, 1995.

Brożen, Mieczysław. Historia literatury łacińskiej w starożytności. Zarys. Wrocław-WarszawaKraków: Zakład Narodowy im. Ossolińskich, 1969.

CANCIK, Hubert \& Helmuth SCHNEIDER, red. Brill's Encyclopaedia of the Ancient World New Pauly, vol. VII. Leiden-Boston: Brill, 2005.

CyCERon. Brutus, czyli o sławnych mówcach. Przełożyła, wstępem i przypisami opatrzyła Magdalena Nowak. Warszawa: Prószyński i S-ka, 2008.

Cytowska, Maria i Hanna Szelest. Literatura grecka i rzymska w zarysie. Warszawa: Państwowe Wydawnictwo Naukowe, $1981\left(1983^{2} ; 1985^{3}\right)$.

Cytowska, Maria i Hanna Szelest. Literatura rzymska. Okres augustowski. Warszawa: Państwowe Wydawnictwo Naukowe, 1990.

Cytowska, Maria i Hanna Szelest. Literatura rzymska. Okres cesarstwa. Warszawa: Państwowe Wydawnictwo Naukowe, 1992.

Cytowska, Maria i Hanna Szelest. Literatura rzymska. Okres cesarstwa: autorzy chrześcijańscy. Warszawa: Państwowe Wydawnictwo Naukowe, 1994.

CytowsKa, Maria i Hanna SzelESt. Historia literatury starożytnej, red. Mieczysław Mejor. Warszawa: Wydawnictwo Naukowe PWN, 2006.

\footnotetext{
${ }^{34}$ Odnotujmy, że zgodność między fazami rozwojowymi języka łacińskiego i periodyzacją literatury rzymskiej dotyczy nie tylko doby republiki, ale także cesarstwa. Epoka łaciny srebrnej składa się bowiem z dwóch opozycyjnych faz historycznoliterackich (okresu imperialnego przypadającego na lata panowania dynastii julijsko-klaudyjskiej, 14-68 r. po Chr., oraz okresu „liberalizmu”, trwającego od panowania Wespazjana do Trajana, 69-117 r. po Chr.), podobnie jak epoka późnej łaciny (wyróżniamy w jej obrębie okres „kompilacji”, 180-333 r. po Chr., oraz okres odrodzenia późnoantycznego, 333-476 r. po Chr.). Jedynie epoka łaciny archaizującej tworzy jednolity okres literacki z archaizmem jako dominującym prądem (117-180 r. po Chr.). Szerzej powyższe zagadnienie zamierzam omówić w pracy pt. Zagadnienie periodyzacji literatury łacińskiej doby cesarstwa rzymskiego [w przygotowaniu].
} 
DufF, John Wight. The Writers of Rome. Oxford: Oxford University Press, 1924 (przedruk: 1962).

DufF, John Wight. A Literary History of Rome. From the Origins to the Close of the Golden Age. 3rd edition. London: Ernest Benn Limited, New York: Barnes \& Noble Inc, $1953^{3}$.

FeENEY, Denis. Beyond Greek. The Beginnings of Latin Literature. Cambridge, MA-London: Harvard University Press, 2016.

Howatson, Margaret C. (red.). The Oxford Companion to Classical Literature. Oxford-New York: Oxford University Press, $1989^{2}$.

Kwintus Horacjusz Flakkus, Dzieła wszystkie. T. II. Tekst łaciński do druku przygotował, wyboru przekładów dokonał, przedmową, życiorysem poety, wersyfikacją i komentarzem opatrzył Oktawiusz Jurewicz. Wrocław: Ossolineum, 1986.

KRZYŻANOWSKI, Julian. „Barok na tle prądów romantycznych”. Przegląd Współczesny r. 16, t. 60, nr 178/179(1937).

KRZYŻANOwSKI, Julian. Od średniowiecza do baroku: Studia naukowo-literackie, 7-53. Warszawa: Towarzystwo Wydawnicze „Rój”, 1938.

KumANiecki, Kazimierz. Literatura rzymska. Okres cyceroński. Warszawa: Państwowe Wydawnictwo Naukowe, 1977.

Lewandowski, Ignacy. Historiografia rzymska. Poznań: Wydawnictwo Poznańskie, 2007.

LÓPEZ, Aurora. „Cornelia, madre de la epistolografia latina”. W Agustín RAMOs GuERREIRA, red. Mnemosynum C. Codoñer a discipulis oblatum, 161-173. Salamanca: Ediciones Universidad Salamanca, 1991.

MARIOTTI, Italo. Storia e testi della letteratura latina. T. II: L'età di Cesare. Bologna: Zanichelli Editore, 1976.

MARKIEWICZ, Henryk. „Próba periodyzacji nowożytnej literatury polskiej”. W Henryk MARKIEWICZ. Przekroje i zbliżenia dawne i nowe. Rozprawy i szkice $z$ wiedzy o literaturze, 5-19. Warszawa: Państwowy Instytut Wydawniczy, 1976.

Markiewicz, Henryk, red. Problemy teorii literatury w Polsce międzywojennej. Wrocław: Zakład Narodowy im. Ossolińskich, 1982, s. 287-320.

MEISER, Gerhard. Historische Laut- und Formenlehre der lateinischen Sprache. Darmstadt: Wissenschaftliche Buchgesellschaft, 2006².

MiкоŁAJCZYк, Ireneusz. Rzymska literatura agronomiczna. Toruń: Wydawnictwo Uniwersytetu Mikołaja Kopernika, 2004.

MoRAwSKI, Kazimierz. Historia literatury rzymskiej. T. I-VII. Kraków: Akademia Umiejętności, 1909-1921.

MORAwSKI, Kazimierz. Zarys literatury rzymskiej. Kraków: Polska Akademia Umiejętności, 1922.

MYŚLIWIEC, Herbert. „Cato”. W Anna ŚwIDERKówNA, red. Stownik pisarzy antycznych, 129-131. Warszawa: Wiedza Powszechna, 1982.

Petrocelli, Corrado. „Cornelia, la matrona”. W Augusto Fraschetti, red. Roma al femminile, 21-70. Roma: Editori Laterza, 1994.

RonCONI, Alessandro. Letteratura latina pagana: profilo storico. Firenze: G.C. Sansoni, 1963.

Rostagni, Augusto. Storia dela letteratura latina. T. I: La repubblica. Torino: Unione Tipografico-Editrice Torinense, 1954. 
RYCHLEWSKA, Ludwika. Dzieje literatury rzymskiej. Wrocław: Wydawnictwo Uniwersytetu Wrocławskiego, 2005.

RychlewsKA, Ludwika, Maria Cytowska i Hanna Szelest. Literatura rzymska. Okres archaiczny. Warszawa: PWN, 1996.

SAfAREwICZ, Jan. Zarys historii języka łacińskiego. Wrocław: Zakład Narodowy im. Ossolińskich, Wydawnictwo PAN, 1986.

SKWARA, Ewa. Historia komedii rzymskiej. Warszawa: Prószyński i S-a, 2001.

SkwarA, Ewa. Komedia wedlug Terencjusza. Warszawa-Toruń: Fundacja na Rzecz Nauki Polskiej, 2016

SŁAwIŃSKI, Janusz, red. Stownik terminów literackich. Wrocław-Warszawa-Kraków: Zakład Narodowy im. Ossolińskich, 1998.

StabryŁa, Stanisław. Historia literatury starożytnej Grecji i Rzymu. Wrocław-Warszawa-Kraków: Zakład Narodowy im. Ossolińskich, 2002.

StABRYŁA, Stanisław. Zarys kultury Grecji i Rzymu. Warszawa: Oficyna Wydawnicza Aspra-JR, Bellona, $2016^{2}$.

Stankiewicz, Lucyna. Komedia Lucjusza Afraniusza i jej zwiazki z innymi odmianami komedii. Wrocław: Wydawnictwo Uniwersytetu Wrocławskiego, 1999.

StANKIEWICZ, Lucyna. Tytyniusz - przedstawiciel komedii rzymskiej zwanej fabula togata. Wrocław: Wydawnictwo UWr, 1987.

SzCZYGIEt, Sylwia. Marek Porcjusz Katon: rzymski tradycjonalista czy polityk realista. Warszawa: Wydawnictwo DiG, 2011.

SzELEST, Hanna. „Epigram rzymski okresu archaicznego”. Meander 58(2003), nr 3-4: 305-318.

TeufFEL, Wilhelm Sigmund. Geschichte der römischen Literatur, neu bearbeitet von Wilhelm KroLL und Franz SkUTSCH. B. I: Die Literatur der Republik. Leipzig-Berlin: B.G. Teubner, $1916^{6}$.

\section{ZAGADNIENIE PERIODYZACJI LITERATURY ŁACIŃSKIEJ DOBY REPUBLIKI RZYMSKIEJ}

\section{Streszczenie}

Artykuł podejmuje problem periodyzacji literatury rzymskiej doby republiki. Autor uznaje tradycyjny podział na 3 okresy literackie: (1) archaiczny; (2) cyceroński; (3) augustowski za częściowo poprawny. Bazując na teorii periodyzacji literatury, opracowanej przez prof. Juliana Krzyżanowskiego (1937), która zakłada cykliczność zjawisk w dziedzinie kultury i literatury, autor proponuje wydzielenie czterech kolejnych faz historycznoliterackich: [1] Okres archaiczny albo „hellenizujący” (240-160 r. przed Chr.); [2] Okres późnoarchaiczny albo „reakcyjny” (160-81 r. przed Chr.); [3] Okres cyceroński (81-31 r. p.n.e.); [4] Okres augustowski (31 r. przed Chr. - 14 r. po Chr.). Poszczególne okresy literackie stoją w wyraźnej opozycji do faz poprzedzających i po nich następujących. Występują w nich dominujące prądy i zjawiska literackie, odmienne niż w fazie poprzedzającej i bezpośrednio po nich następującej. Biorąc pod uwagę kryterium wpływów obcych (helleńskich) i rodzimości, możemy łatwo stwierdzić, że okresy nieparzyste $[1,3]$ mają charakter wyraźnie prohelleński, co przejawia się między innymi w thumaczeniu bądź adaptacji najważniejszych dzieł literatury greckiej, wykorzystaniu istniejących w Grecji gatunków literackich, przyswojeniu obcych struktur metrycznych, motywów literackich lub prądów filozoficznych, podczas gdy w okresach 
parzystych $[2,4]$ twórcy literatury łacińskiej wprowadzają rodzime wątki i czysto rzymskie motywy, a także rozwijają własne gatunki literackie (np. satyrę, rzymską elegię miłosną).

Słowa kluczowe: język łaciński; literatura rzymska; okres literacki; Rzym; teoria periodyzacji Juliana Krzyżanowskiego; wpływy greckie.

\section{THE ISSUE OF PERIODIZATION OF THE LATIN LITERATURE IN THE TIME OF THE ROMAN REPUBLIC}

\section{Summary}

The article deals with the problem of periodization of Latin literature in the time of the Roman Republic. The author recognizes the traditional division into three literary periods (i.e. archaic, Ciceronian and Augustean) as partially correct. Basing on J. Krzyżanowski's theory of periodization of literature (1937), which assumes the cyclical nature of phenomena in the field of culture and literature, the author proposes to separate four successive historical-literary phases: [1] the early-archaic or "Hellenizing" period (240-160 BC); [2] the late-archaic or "reactionary" period (160-81 BC); [3] the Ciceronian age (81-31 BC); [4] the Augustean age (31 BC-14 AD). The individual literary periods stand in clear opposition to the preceding and following phases. They contain dominant currents and literary phenomena, different than in the preceding and immediately following them. Taking into account the criterion of foreign (Hellenic) influences and nativity, we can easily conclude that odd periods $[1,3]$ are clearly favorable to the Greeks, which is manifested, inter alia, in translating or adapting the most important works of Greek literature, using literary genres existing in Greece, acquiring foreign metrical structures, literary motifs or philosophical currents, while in even periods $[2,4]$ Latin writers introduce native themes and purely Roman motifs, as well as develop their own literary genres (e.g. Roman satire, subjective love elegy).

Key words: Latin language; Roman literature; literary period; Rome; Julian Krzyżanowski's theory of periodization; Greek influences. 